UDC 004.738.5:339.93.:334.012.61- 022.5

JEL Classification: M21, M15

KONDRATIUK Oksana,

$\mathrm{PhD}$ (Economics), Associate Professor,

Associate Professor of the Department of Economics and Business Finance Kyiv National University of Trade and Economics 19, Kyoto str., Kyiv, 02156, Ukraine

E-mail: o.kondratyuk@knute.edu.ua ORCID: 0000-0002-2750-6867
DOI: http://doi.org/10.31617/visnik.knute.2020(134)03

STOIANENKO Iryna, $\mathrm{PhD}$ (Economics), Associate Professor, Associate Professor of the Department of Economics and Business Finance Kyiv National University of Trade and Economics 19, Kyoto str., Kyiv, 02156, Ukraine

E-mail: i.stoyanenko@knute.edu.ua ORCID: 0000-0002-1775-9473

\title{
DIGITALIZATION OF BUSINESS UNDER GLOBAL CHALLENGES
}

The article focuses attention on prospects for the development of Ukraine's economy taking into account the potential of social processes and business digitalization. We accentuated the global tendencies of economic relations digitalization, which create progressive forms and methods of business processes for small and medium enterprises. The article determined priorities of development for small and medium businesses of Ukraine under the conditions of the pandemic, world economic crisis, and digital transformation of economic relations.

Keywords: digitalization, digital technologies, digital economy, digital platforms, business processes, small and medium business.

Background. Modern conditions of work for small and medium-sized businesses are characterized by a very high level of dynamism, so running a business with old business models means exposing yourself to the risk of being behind competitors. Accelerating the pace of informatization and digitalization, on the one hand, increases the risks for existing business models, but on the other hand, it opens up new opportunities for business development.

According to a study conducted by Huawei and Arthur D. Little [1], in $2016,60 \%$ of companies began to use digital technologies and change their business; $20 \%$ of companies have just started to get acquainted with digital; $18 \%$ attracted and served customers with the help of information technologies; $2 \%$ are completely digitalized. In 2016 the digital economy accounted for $15.5 \%$ of world GDP, in 2022, according to experts from Huawei and Oxford Economics calculations, this figure could reach $60 \%$ [2].

Nowadays, digitalization is becoming a necessary condition for doing business, which affects not only work with customers but also internal processes related to production, management, internal communication. Particular attention is paid to the applied aspect of digitalization, ie the possibility of its application in the practice of enterprises, which encourages the latter to constantly increase the set of digital tools and expand their scope.

(C) Kondratiuk O., Stoianenko I., 2020 
According to a McKinsey company study, businesses, and organizations that have switched to digital competition have 2.5 times more active revenue growth, better EBIT and ROI indicators. Conversely, in the case of a slowdown in digital transformation, companies estimate the probability of revenue loss in the next 3 years at $25-40 \%$ depending on the industry [3].

Analysis of recent research and publications. Theoretical and applied aspects of digital economy formation and development are highlighted in the works of such foreign researchers as A. Toffler and H. Toffler [4], they point out that information can replace a large number of material resources and will become the main material for employees. B. Larralde and P. Hagen [5] emphasize that the use of digital tools leads to radical changes in our lives, makes us think in new ways, plan and make decisions.

Among national scientists who study the problems of the digital economy and its impact, in particular, on the activities and development of domestic enterprises, it is worth noting the works of O. Abakumenko, Y. Bazhal, V. Varga, O. Gudz, A. Derkach, I. Dulska, K. Kononova, M. Korneeva, S. Korol, N. Kraus, V. Makoviy, E. Polovyk, O. Halapsis, and others.

Thus, Yu. Bazhal [6] focuses on the ability of small businesses to implement digital tools in business, which provides advantages over large corporations when it is necessary to dynamically commercialize the latest technologies or meet innovative consumer demand. The advantage of small innovative entrepreneurship is its ability to quickly introduce new products, modernize and disseminate them through cooperation with both large businesses and consumers, adapting new product properties to possible innovative needs, as well as being a link between industry science and public research sector, universities and other participants of innovation processes.

In turn, K. Kononova pays attention to the information economy, the use of artificial intelligence, and their impact on the activities of enterprises [7]. $\mathrm{N}$. Kraus considers the digital economy as one that is based on digital computer technology. The researcher focuses on the description of this type of economy basic components and innovative services/products [8].

Taking into consideration the urgency of this problem and the growing need for digital tools for small and medium business entities, the questions of new ways to manage the economic and social changes associated with the digital transformation demand more in-depth research.

The aim of this work is to substantiate the modern vision of society digitalization manifestation and determine a set of tools for enterprises' digitalization, including small and medium-sized businesses under the conditions of global challenges.

Materials and methods. The informational bases of the research were publications of national and foreign scientists on the research topic, statistical materials, and Internet sources. To fulfill the set tasks and achieve the main goal of the research we used methods of generalization, analysis and synthesis, comparison, scientific abstraction and systematization. 
Results. The term"digitalization" is an English word, which means "digitization". However, scientists are increasingly using this definition based on its practical aspect, and therefore the terms "digitalization" have become widespread.

O. Abakumenko, A. Derkach and M. Korneeva interpret the concept of "digitalization" as a process of converting a certain information field from analog to digital format for easier further use on modern electronic devices [9]. O. Halapsis defined this definition as "digitization of being", that is not only the mass use of digital technologies but the process of bringing into an electronic form the various types of information used by people, covering all spheres of life [10]. In the scientific works of national researchers we can also find the interpretation of digitalization as a system of data collection, storage, analysis and use of artificial intelligence [11] or "... the process of using the modern information and communication technologies based on the capabilities of the modern IT industry, for the transformation of existing business processes by their digitalization "[12].

$\mathrm{V}$. Varga emphasizes on the applied aspect and importance for using it in the practical activities of enterprises, taking into account the existing definitions in national publications, characterizing digitalization as "the process of systematization, use, processing of information in digital format to improve customer service in the business environment" [13]. According to the scientist, its effective application in daily activities will ensure the formation of stable competitive advantages of enterprises both in the current and in future periods.

Thus, digitalization under the conditions of the modern economy and global challenges is one of the main tools for enterprise development aimed at the successful management of all business processes. Digitalization gives a possibility to simplify and carry out work at a faster pace, using large databases, providing automation of all activities - both basic and investment and financial; improve communication between customers, suppliers and partners; increase mobility in interaction within the enterprise - between departments, employees, management; make the transition to such new organizational forms of management as a network or virtual economy.

According to a study by the International Telecommunication Union at the United Nations, the number of Internet users increased from $25.8 \%$ of the world's population in 2009 to $53.6 \%$ in 2019 , when 4.1 billion people in the world were connected to the Internet [14]. Therefore, it should be expected that the development of the Internet will expand the network of penetration of digitalization into all spheres of life of both individuals and enterprises. The spread of technology leads to a significant reduction in the share of the traditional economy in the global economic system and an active transition to the digitalization of all spheres of public life.

For the economy of Ukraine, which is in crisis, it is important to form and implement new highly effective ideas of economic growth, one of which, according to I. Dulska, is the introduction of information and communication technologies (ICT) into all sectors of the national economy [15]. 
Thus, the emergence of $3 \mathrm{G}$ connection, according to the scientist, has become one of the catalysts for the domestic economy. according to research by Deloitte, in all markets where $3 \mathrm{G}$ appeared, GDP grew by at least $1 \%$ (figure 1).

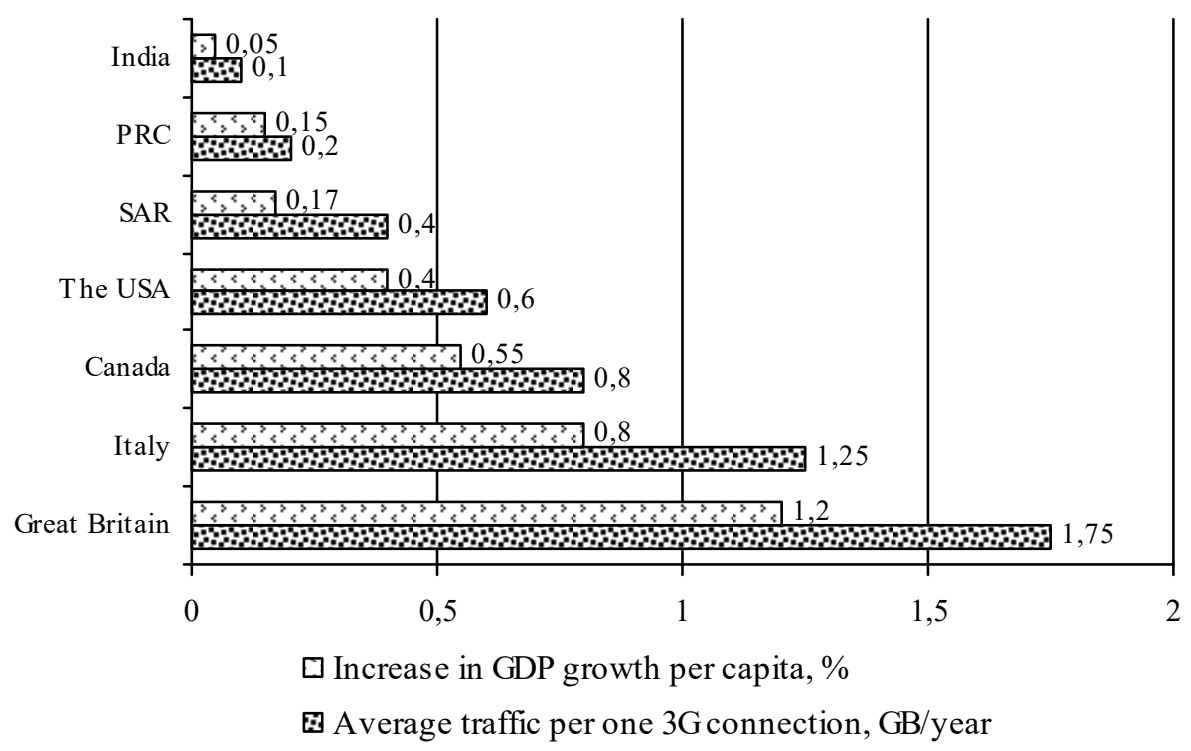

Figure 1. The effect of doubling the mobile use of data over 3G-connection on the increasing of GDP growth

Source: generated by the authors according to [15].

The explanation for such positive changes is that the possibilities of using this coverage contribute to the development not only of telecom operators but also of other branches of business, as management decisions are made faster and the space for small and medium-sized businesses expands.

In Ukraine, the introduction of $3 \mathrm{G}$ connection was characterized by a rather long time lag, as in 2007-2014 Ukrtelecom was licensed to implement it. However, its management did not pay enough attention to the development of this technology, and only in February 2015, a tender was held in which real competitors purchased three licenses. Currently, most of Ukraine has adequate coverage, but the share of rural population covered by the mobile network in our country, compared to other countries where the share of coverage in 2011-2012 was more than 90\% (in the UAE and Bahrain $100 \%$, Greece and Canada - $95 \%$, Sweden and Armenia - $93 \%$, Bulgaria $92 \%$ [15]), is still low.

Since 2018, 4G has been actively used in Ukraine. The coverage already takes the territory inhabited by $77 \%$ of the population of Ukraine (mostly large and medium-sized cities, where $82 \%$ of the population lives) [16]. The need for high-quality mobile connection has become especially acute in the context of the COVID-19 pandemic, in particular for those settlements where there is no wired Internet. Currently, about $70 \%$ of business customers who use $4 \mathrm{G}$ download data to cloud storage, $80 \%$ use messengers and online applications that allow them to communicate with customers and promote their products.

ISSN 1727-9313. HERALD OF KNUTE. 2020. NN 6 
Today in the world, companies and organizations successfully use $5 \mathrm{G}$, in particular, in manufacturing, logistics, agriculture, transport. Looking to the future, there are prospects for using the capabilities of this coverage in telemedicine, robotics, remote control, and transport control [17].

Business players must actively generate new business ideas in order not to lose market position. The slowdown in the economic growth in early 2020 with the global pandemic COVID-19 will have significant negative consequences for the economy in Ukraine (the official forecast of GDP decline, up to $7 \%$ ), on the one hand, and new living and economic conditions acelerate the introduction of digital technologies for the small and medium businesses on the other hand.

According to the Draft "Industry Development Strategy" 4.0 [18], the positive preconditions for the digitalization of Ukrainian businesses are a developed IT industry and a strong free economic system, while the introduction of negative factors include weak domestic demand for digital innovations, which is probably due to the awareness lack of representatives in small and medium business with digital economy opportunities.

The main advantages of business digitalization are presented in the table.

Table

\section{Advantages of digitalization for enterprises}

\begin{tabular}{|c|l|}
\hline Advantages & \multicolumn{1}{|c|}{ Content } \\
\hline $\begin{array}{c}\text { Optimization } \\
\text { of business-process }\end{array}$ & $\begin{array}{l}\text { All process chains are revised due to the possibility } \\
\text { of flexible adaptation to different conditions in modern business. } \\
\text { Removing outdated templates makes it possible to use existing human } \\
\text { resources more efficiently }\end{array}$ \\
\hline $\begin{array}{c}\text { Opportunities } \\
\text { to increase profits }\end{array}$ & $\begin{array}{l}\text { With new digital technologies, the potential for profit is increasing, } \\
\text { in particular, due to the increase in the number of potential buyers }\end{array}$ \\
\hline Focus on customer needs & $\begin{array}{l}\text { Customer is the main subject for income, so the digitization } \\
\text { of processes will provide an opportunity to master the information } \\
\text { about the customer's needs at each stage of interaction and create } \\
\text { all the conditions to meet customer's needs }\end{array}$ \\
\hline $\begin{array}{c}\text { Optimal growth } \\
\text { of innovations }\end{array}$ & $\begin{array}{l}\text { The rapid growth in the number of innovation processes will provide } \\
\text { an opportunity to respond to problems quickly with increasing } \\
\text { the business efficiency and reducing potential costs }\end{array}$ \\
\hline $\begin{array}{c}\text { Increasing the volume } \\
\text { of data and opportunities } \\
\text { for the use }\end{array}$ & $\begin{array}{l}\text { Prompt, reliable information, including about potential buyers, } \\
\text { partners or competitors, will help expand relationships and improve } \\
\text { communications }\end{array}$ \\
\hline $\begin{array}{c}\text { The use of artificial intelligence in } \\
\text { the production process }\end{array}$ & $\begin{array}{l}\text { The use of robotics and biotechnology in production processes } \\
\text { will help improve technological processes }\end{array}$ \\
\hline
\end{tabular}

Source: generated by the authors according to [19].

Business digitalization processes, according to L. Labeznyk [20] promote electronic communication, which increases the effectiveness of interaction between buyers and sellers and creates new markets and opportunities for economic processes, expands the network of potential buyers, and reduces the cost of electronic communications due to low transmission costs data and significantly increases the speed of the exchange. All these actions lead to an increase in the turnover of financial resources of enterprises, and hence the successful conduct of business. 
The development of small entities is necessary to support the economy of the country as a whole, as they provide jobs and increase the number of skilled workers at relatively low capital costs, create a healthy competetive environment and can protect society from market monopolization. In the periods of structural changes in the economic and political life of the country, small and medium-sized businesses are the main units of structural economic and political transformations and facilitates and remotes the rapid transition and adaptation of the country to the new technological system. An economy with a high amount of small and medium enterprises and entrepreneurs has a lot of important advantages, including inclusive stable economic growth based on knowledge and innovation; flexibility and adaptability to new economic realities.

The easiest way to improve the business processes of the enterprise, making maximum use of the electronic component, is possible in the field of product sales. Thus, according to the State Statistics Service, $89 \%$ of all Ukrainian enterprises work in the services sector, and they account for almost $45 \%$ of employment. They generate $56 \%$ of value-added [21]. Almost half of the value-added of business services is formed in the wholesale and retail sectors.

More than a third of the 100 largest US retailers believe it is possible to increase their income by providing e-commerce services. From the participation in the global electronic market in 2012-2015, US network trading companies had received revenues of $\$ 375$ billion, and by 2020 they plan to increase it to $\$ 535$ billion [20]. Therefore, at the beginning of the XXI century, the increase of participants number in the Ukrainian e-commerce market segment and their high interest in e-commerce systems became regular.

In July 2020, the results of the rating compiled by the online publiccation Retailers, the most popular online stores among Ukrainians were published on the E\&Lnews website-E-Commerce and Logistics (figure 2).

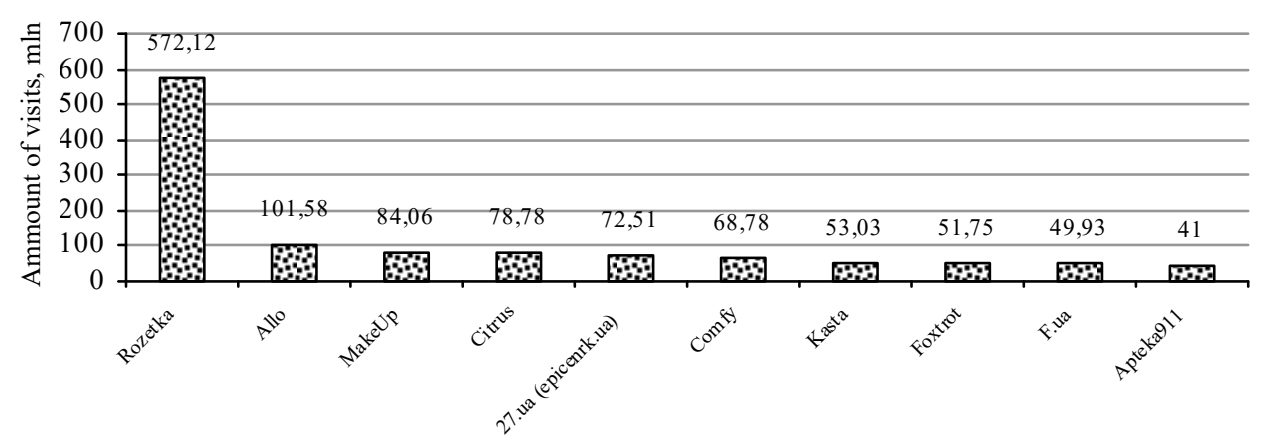

Figure 2. Rating of the most visited online stores in Ukraine, 2019

Source: developed by the authors according to [22].

The marketplace Rozetka became the leader in the number of visits by a large margin from other online stores -572.12 million visits. The second position was taken by the online store Allo (almost 102 million visits). MakeUp, Citrus, and epicenrk.ua online stores are also among the top five. 
So, modern electronic communications based on Internet technologies provide small and medium-sized businesses: expansion and development of new markets; expanding the network to attract new customers, which are no longer limited to the territory; term reduction for carrying out cases; possession of the operational information which is necessary to respond to market changes.

The experience has shown that e-commerce systems can save up to $15 \%$ on purchases and $22 \%$ on sales by optimizing logistics channels, consoledating purchases, reducing intermediary surcharges and achieving optimal prices.

In January 2018, the Concept of Development of the Digital Economy and Society in Ukraine for 2018-2020 was approved [23]. Due to this Concept, there have been created conditions for the beginning of more rapid development in digital technologies and their further implementation in the economy of Ukraine. In particular, the provision of administrative services, according to the preliminary digitalization of processes, has provided an opportunity to continue the financial activities of enterprises and individuals with the use of Internet resources through ordering services online, even in strict quarantine.

Although the digital economy in Ukraine has not reached a large scale compared to developed foreign countries, these countries also have problems with the implementation of the digital transformation. According to the results of the study Riverbed Digital Performance, conducted by the American company Riverbed Technology in nine countries - USA, UK, Brazil, Germany, Australia, France, China, Singapore, India (objects of the study - 1000 companies in the field of retail, transport, industry, health care, finance with an annual income of more than $\$ 500$ million) - $95 \%$ of survey participants said they are not ready to implement a digital strategy in their companies nowadays. Only $10 \%$ of companies in the world have completely switched to digital technology in their activities, and only $26 \%$ are ready to change [24].

Today, domestic enterprises not only automate business processes but also create their control and analysis tools for effective management. According to O. Hudz and V. Makova [25], enterprises, that do not develop and implement digital transformation strategies, will be inefficient tomorrow and will simply disappear under the pressure of new market realities and more pragmatic and successful competitors.

Conclusion. The traditional economy is affected by the digitalization of business relations, which modernizes and transforms business processes, under the influence of which changes not only the structure of the market participants but also the technology of management. The development of digitalization at enterprises in Ukraine should be facilitated by the spread of 5Gnetwork, training of qualified personnel specializing in electronic communications, development of new services for convenient delivery of online orders, development and improvement of electronic payment systems.

The issues of digitalization became especially acute in the quarantine conditions when the trend is to sell goods online and carry out activities at a distance. The global economic crisis caused by the COVID-19 pandemic requires small and medium-sized businesses to adapt to multi-vector priorities, which will be dominated by such development trends in the short term. 
Internationalization, which gives such enterprises new growth opportunities, contributing to the economic stability of the country. This can be product exports, licensing, franchising, joint ventures, relocation of production, and so on.

Localization. Local production is valuable for the consumer because it provides additional quality guarantees and a higher level of availability. Opportunity for small and medium-sized businesses to work with large retail chains (it applies to farms and producers of industrial consumer goods). Large commercial enterprises can promote small and medium-sized businesses by taking joint and several responsibilities for the quality and safety of goods. In addition to retail chains, the pharmaceutical industry is interested in the local manufacturer. For this industry, local producers are more transparent and open, and quality standards, licensing conditions, equipment, and business processes have met European requirements. Besides, the product quality is strictly regulated by local government services and regulations, which are already synchronized with European ones.

The use of digital platforms is important in nowadays environment. They transform not only trading platforms, but also the market of services, agriculture, educational services and provide the opportunity to develop small and medium-sized businesses in various areas of the modern economy.

Through the use of digital tools, businesses gain several benefits that increase competitiveness, save costs, simplify working with large data sets, improve the company image and increase customer loyalty.

\section{REFERENCES}

1. Think differently. Think archetype. Your digital economy model. Huawei ta Arthur D. Little. www.huawei.com. Retrieved from https://www.huawei.com/-/media/ corp2020/pdf/public-policy/adl_huawei_digital_transformation_main_report.pdf?la=en (accessed 27 September 2020) [in English].

2. Digital Spillover Measuring the true impact of the digital economy. www.huawei.com. Retrieved from https://www.huawei.com/minisite/gci/en/digitalspillover/files/gci_digital_spillover.pdf (accessed 27 September 2020) [in English].

3. McKinsey. Official website. www.mckinsey.com. Retrieved from https://www.mckinsey.com/industries/technology-media-and-telecommunications/ our-insights (accessed 27 September 2020) [in English].

4. Toffler, A., \& Toffler, H. (2005). Revolutionary wealth. New York: Knopfp [in English].

5. Hagen, R. (2018). The End of Ownership: Personal Property in the Digital Economy. Science and Public Policy, 45. Iss. 1, 137-139 [in English].

6. Bazhal, Ju. M. (2016). Misce i rol' malogo biznesu v innovacijnij modeli ekonomichnogo rozvytku [The place and role of small business in the innovative model of economic development]. Problemy innovacijno-investycijnogo rozvytkuProblems of innovation and investment development, 9, 43-46. Retrieved from http://nbuv.gov.ua/UJRN/Piir_2016_9_6 (accessed 27 September 2020) [in Ukrainian].

7. Kononova, K. Ju. (2015). Informacijna ekonomika: modeljuvannja evoljucijnyh procesiv [Information economics: modeling of evolutionary processes]. Harkiv: HNU imeni V. N. Karazina [in Ukrainian]. 
8. Kraus, N. M., Kraus, K. M. (2018). Cyfrovizacija v umovah instytucijnoi' transformacii' ekonomiky: bazovi skladovi ta instrumenty cyfrovyh tehnologij [Digitization in the conditions of institutional transformation of economy: basic components and tools of digital technologies]. Intelekt XXI - Intelligence XXI, 1, 211-214 [in Ukrainian].

9. Abakumenko, O., Derkach, A., \& Kornjejeva, M. (2016). Dydzhytalizacija bankivs'kogo sektoru [Digitalization of the banking sector]. Finansovi doslidzhennja - Financial research,1 (1), 69-75. Retrieved from https://fr.stu.cn.ua/ tmppdf/20.pdf (accessed 27 September 2020) [in Ukrainian].

10. Halapsys, A. V. Globalyzacyja y metryka ystoryy [Globalization and the metrics of history]. halapsis.net. Retrieved from http://halapsis.net/globalizatsiya-imetrika-istorii (accessed 27 September 2020) [in Russian].

11. Korol', S. Ja., \& Pol'ovyk, Je. V. (2019). Dydzhytalizacija ekonomiky jak faktor profesijnogo rozvytku [Digitalization of the economy as a factor of professionnal development]. Modern Economics, 18, 67-73. Retrieved from https://modecon.mnau.edu.ua/ digitization-of-the-economy-as (accessed 27 September 2020) [in Ukrainian].

12. Gudz', O., Fedjunin, S., \& Shherbyna V. (2019). Dydzhytalizacija, jak konkurentna perevaga pidpryjemstv [Digitalization as a competitive advantage of enterprises]. Ekonomika. Menedzhment. Biznes - Economy. Management. Business, 3(29), 18-24. Retrieved from http://journals.dut.edu.ua/index.php/emb/article/ view/2215 (accessed 27 September 2020) [in Ukrainian].

13. Varga, V. P. (2020). Dydzhytalizacija jak odyn z chynnykiv konkurentospromozhnosti pidpryjemstva [Digitalization as one of the factors of enterprise competitiveness]. Efektyvna ekonomika - Efficient economy, 8. Retrieved from $\mathrm{http}: / / \mathrm{www}$. economy.nayka.com.ua/?op=1\&z=8121 (accessed 27 September 2020) [in Ukrainian].

14. OON: 4,1 mil'jarda ljudej u sviti pidkljucheni do internetu. Sajt Radio "Svoboda" [UNO: 4.1 billion people in the world are connected to the Internet. Radio Liberty website]. www.radiosvoboda.org. Retrieved from https://www.radiosvoboda.org/ a/news-oon-internet/30254946.html (accessed 27 September 2020) [in Ukrainian].

15. Dul's'ka, I. V. (2015). Cyfrovi tehnologii' jak katalizator ekonomichnogo zrostannja [Digital technologies as an indicator for economic growth]. Ekonomika i prognozuvannja - Economics and Forecasting, 2,121-122 [in Ukrainian].

16. Mobil'naja svjaz' 4G dostupna bolee chem v polovine naselennyh punktov Ukrainy. Mincifry. Informacijne agentstvo "Interfaks-Ukrai'na" [4G mobile communication is available in more than half of the settlements of Ukraine. Minnumbers. Interfax-Ukraine News Agency]. interfax.com.ua. Retrieved from https://interfax.com.ua/news/telecom/661942.html (accessed 27 September 2020) [in Russian].

17. Specialisty o 5G v Ukraine. Vozmozhnosti i vyzovy. Sajt hi-tech [Specialists about $5 \mathrm{G}$ in Ukraine. Opportunities and challenges. Website hi-tech]. hi-tech.ua. Retrieved from https://hi-tech.ua/spetsialistyi-o-5g-v-ukraine-vozmozhnosti-ivyizovyi (accessed 27 September 2020) [in Russian].

18. Projekt Nacional'noi' strategii' Industrii' 4.0. Oficijnyj sajt Asociacii' pidpryjemstv promyslovoi' avtomatyzacii' Ukrai'ny [Draft of National Industry Strategy 4.0. Official website of the Association of Industrial Automation Enterprises in Ukraine]. mautic.appau.org.ua. Retrieved from https://mautic.appau.org.ua/ asset/42:strategia-rozvitku-4-0-v3pdf (accessed 27 September 2020) [in Ukrainian]. 
19. Dligach, A. Cyfrova transformacija jak lift u majbutnje [Digital transformation as an elevator to the future]. Retrieved from https://tqm.com.ua/ua/likbez/uaarticles/cyfrova-transformaciya-yak-lift-u-majbutnye (accessed 27 September 2020) [in Ukrainian].

20. Labeznyk, L. L. (2018). Dydzhytalizacija ekonomichnyh vidnosyn jak faktor udoskonalennja biznes-procesiv na pidpryjemstvi [Digitalization of economic relations as a factor in improving business processes at the enterprise]. Ekonomichnyj visnyk - Economic Bulletin, 213, 69-74 [in Ukrainian].

21. Zbirnyk statystyky pidpryjemnyctva v Ukrai'ni: 2018. Derzhavna sluzhba statystyky Ukrai'ny: oficijnyj sajt [Collection of business statistics in Ukraine: 2018. State Statistics Service of Ukraine: official website]. Retrieved from http://www.ukrstat.gov.ua (accessed 27 September 2020) [in Ukrainian].

22. Rejtyng vidviduvanosti ukrai'ns'kyh internet-magazyniv za 2019 rik [Attendance rating of Ukrainian online stores in 2019]. Retrieved from https://elnews.com.ua/ uk/rejtyng-vidviduvanosti-ukrayinskyh-internet-magazyniv-za-2019-rik (accessed 27 September 2020) [in Ukrainian].

23. Pro shvalennja Koncepcii' rozvytku cyfrovoi' ekonomiky ta suspil'stva Ukrai'ny na 2018-2020 roky ta zatverdzhennja planu zahodiv shhodo i'i' realizacii': rozporjadzhennja Kabinetu Ministriv Ukrai’ny vid 17.01.2018 № 67-r. [On approval the Concept of development of the digital economy and society in Ukraine for 2018-2020 and approval of the action plan for its implementation: order by the Cabinet of Ministers of Ukraine dated January 17, 2018 № 67-r]. Retrieved from https://zakon.rada.gov.ua/laws/show/67-2018-\%D1\%80\#Text (accessed 27 September 2020) [in Ukrainian].

24. $95 \%$ kompanyj ne gotovy $\mathrm{k}$ cyfrovoj transformacyy [95\% of companies are not ready for digital transformation]. Riverbed Technology. Website "Retail\& Loyalty". Retrieved from https://retail-loyalty.org/news/95-kompaniy-ne-gotovyk-tsifrovoy-transformatsii-riverbed-technology (accessed 27 September 2020) [in Russian].

25. Gudz', O. Je., \& Makovij, V. V. (2018). Rozroblennja strategii' Digital-transformacii' pidpryjemstv [Development of Digital Enterprise Transformation Strategy]. Infrastruktura rynku - Market Infrastructure, 25, 248-254 [in Ukrainian].

The article submitted to editor's office on 29.09.2020. викликів.

Кондратюк О., Стояненко І. Диджиталізація бізнесу в умовах глобальних

Постановка проблеми. Умови, в яких сьогодні доводиться працювати малому та середньому бізнесу, характеризуються надвисоким рівнем динамізму, тому здійснювати діяльність, використовуючи старі бізнес-моделі, означає наражати себе на ризик залишитися позаду конкурентів. Нині диджиталізаџія стає необхідною умовою ведення бізнесу, яка зачіпає не тільки роботу з клієнтами, але і внутрішні процеси, пов'язані з виробництвом, управлінням, комунікаціями.

Метою иісї роботи є обтрунтування сучасного бачення прояву диджиталізації суспільства та визначення набору інструментів диджиталізачії діяльності підприсмств, у тому числі малого та середнього бізнесу в умовах глобальних викликів.

Матеріали та методи. Інформаційною базою дослідження слугували публікації вітчизняних та зарубіжних науковців за темою дослідження, статистичні матеріали та інтернет-джерела. Для виконання поставлених завдань $і$ досягнення основної мети дослідження застосовано методи узагальнення, аналізу та синтезу, порівняння, наукового абстрагування та систематизації.

ISSN 1727-9313. HERALD OF KNUTE. 2020. № 6 
Результати дослідження. Диджиталізація в умовах сучасної економіки є одним із головних інструментів розвитку підприємств, спрямованих на успішне ведення усіх бізнес-прочесів. Завдяки диджиталізації з'являється можливість спростити та здійснювати роботу в більш швидкому темпі, використовуючи великі бази даних, забезпечуючи автоматизачію всіх видів діяльності, як основної, так інвестиційної та фінансової, покращити комунікацію між клієнтами, постачальниками та партнерами, збільшити мобільність у взаємодії у межах підприємства - між підрозділами, прачівниками, менеджментом, здійснити перехід до таких нових організачійних форм господарювання, як мережева чи віртуальна економіка.

Висновки. Світова економічна криза, спричинена пандемією COVID-19, вимагає від суб'єктів малого та середнього бізнесу адаптациї до різновекторних пріоритетів, серед яких у короткостроковій перспективі домінуватимуть такі тендениіі розвитку: інтернаціоналізація, локалізація та використання диджитал-платформ.

Ключові слова: диджиталізація, диджитал-технології, диджитал-економіка, диджитал-платформи, бізнес-процеси, малий та середній бізнес.

UDC 453.87.35

JEL Classification: F23, O15

DOI: http://doi.org/10.31617/visnik.knute.2020(134)04

BUSARIEVA Tatiana,

$\mathrm{PhD}$ (Economics), Associate Professor,

doctoral student of the World Economy Department

of Kyiv National University of Trade and Economics

19, Kyoto str., Kyiv, 02156, Ukraine

E-mail:sutner@ukr.net

ORCID: 0000-0001-9563-8120

\section{THE UNIVERSAL MODEL OF KNOWLEDGE MANAGEMENT OF CORPORATIONS}

The components of the universal model of knowledge management of TNCs are considered and human, structural, innovative capital and capital of relations are characterized. Measurements of intellectual capital and sources of its quantitative assessment in the context of knowledge management are analyzed. It is proved that in the conditions of the formation of the knowledge economy and limited resources, the possibility of introducing a knowledge management system in an organization is its main competitive advantage. The role of the knowledge management model in ensuring the effectiveness of TNCs is established.

Keywords: knowledge economy, TNC, knowledge management, resource management, R\&D, knowledge management model.

(C) Busarieva T., 2020 